Chirurgia (2018) 113: 687-694

No. 5, September - October

Copyright $\odot$ Celsius

http://dx.doi.org/10.21614/chirurgia.113.5.687

\title{
Tumor is an Oxidative Stress Factor in Ovarian Cancer Patients
}

\author{
Oana Trifanescu ${ }^{1,2}$, Maria Iuliana Gruia', Laurentia Gales ${ }^{1,2}$, Raluca Trifanescu ${ }^{2,3}$, Rodica Anghel ${ }^{1,2}$ \\ 1"Prof. dr. Alexandru Trestioreanu" Institute of Oncology, Bucharest, Romania \\ 2"Carol Davila" University of Medicine and Pharmacy, Bucharest, Romania \\ "'C.I Parhon" Bucharest Institute of Endocrinology, Bucharest, Romania
}

Corresponding author:

Oana Trifanescu, M.D.

Prof. Dr. Al. Trestioreanu Institute of

Oncology

252 Fundeni Street, 7th Floor, 22328,

Bucharest, Romania

E-mail: oanatrifanescugab@yahoo.com

Received: 26.08 .2018

Accepted: 21.09 .2018

\section{Rezumat}

\section{Tumora factor de stres oxidativ în cancerul ovarian}

Introducere: Adenocarcinomul ovarian reprezintă la nivel global, a doua cauză de neoplazie în rândul tumorilor ginecologice, dar este principala cauză de mortalitate prin tumori ginecologice. Scopul acestui studiu a fost să identifice intensitatea stresului oxidative la pacienții cu adenocarcinom ovarian şi să identifice relațile dintre diferite specii reactive de oxigen (ROS) şi prezența tumorii reziduale. Pacienți şi metode: Treizeci-şi-cinci paciente cu adenocarcinom ovarian stadiul II-IV, diagnosticate între 2010-2017, care au primit tratament multimodal constând în intervenție chirurgicală şi chimioterapie pe baza de săruri de platină au fost incluse în studiu. ROS măsurate în dinamică (4 determinări înaintea fiecărui ciclu de chimioterapie) au fost malondialdehida pentru evaluarea peroxidării lipidice, cerulosplamina, grupările tiol şi antioxidanții totali.

Rezultate: S-a înregistrat o creştere sistematică a valorilor ROS: valorile medii ale malondialdehidei au fost de $8.1 \mu \mathrm{mol} / 100 \mathrm{ml}$ (valorile normale sub $4 \mathrm{\mu mol} / 100 \mathrm{ml}$ ); valoarea media a ceruloplasminei a fost de 144.8 U.I. (normal 120U.I). Ambele valori crescute arată că tumora induce un important proces oxidativ. Valorile tiolilor au fost puțin scăzute față de valorile normale (395 vs. 450 $\mu \mathrm{mol} / \mathrm{l})$. S-a constat o uşoară creştere a valorilor antioxidanților totali (1.44 vs $1.4 \mathrm{\mu mol}$ ). Toți aceşti patru compuşi au scăzut între prima şi a patra determinare. S-a înregistrat o corelație puternică între malondialdehida şi ceruloplasmină (coeficient Pearson 0.315 $\mathrm{p}=0.005$ ) şi între peroxidarea lipidică şi grupările tiolice (coeficient Pearson $0.23 \mathrm{p}=0.039$ ), precum şi între grupările tiolice şi antioxidanți (coeficient Pearson $0.33 \mathrm{p}=0.003$ ). Peroxidarea lipidică şi 
ceruloplasmina au fost semnificativ mai crescute la pacientele cu tumora reziduală ( $\mathrm{p}=0.039$ şi $\mathrm{p}=0.046)$ subliniind rolul tumorii ca factor generator al stresului oxidativ.

Concluzii: Tumora produce în exces ROS la pacienți cu adenocarcinom ovarian. Aceste ROS se află în inter-relație strânsă şi acționează ca molecule de semnalizare

Cuvinte cheie: specii reactive de oxigen, adenocarcinom ovarian

\section{Abstract}

Introduction: Epithelial ovarian cancer is worldwide the second cause of gynaecological cancer but the commonest cause of gynaecological cancer-associated death.

Aim: To determine the intensity of oxidative stress in ovarian cancer patients and to establish a connection between the presence of the tumor and reactive oxygen species (ROS).

Patients and methods: Thirty-five patients diagnosed with epithelial ovarian carcinoma stage II-IV between 2010 and 2017, who underwent multimodality treatment (surgery and chemotherapy) were included in the study. ROS measured in dynamic (four determinations between every cycle) were malondialdehyde to evaluate the lipid peroxidation, ceruloplasmin, $\mathrm{SH}-$ albumin thiols groups and total antioxidants.

Results: There was an increase in the value of ROS: malondialdehyde mean value was $8.1 \mu \mathrm{mol} / 100$ $\mathrm{ml}$ (normal value $4 \mu \mathrm{mol} / 100 \mathrm{ml}$ ); ceruloplasmin mean value was 144.8 U.I. (normal value 120U.I), both showing an active oxidative process in patients with ovarian cancer. A small decrease of the value of thiols (395 vs. $450 \mu \mathrm{mol} / \mathrm{l}$ ) and a small increase of total antioxidants was noticed (1.44 vs. $1.4 \mathrm{umol}$ ). All four compounds decrease between the first determination and the fourth one. There was a strong correlation between lipid peroxides levels and ceruloplasmin (Pearson correlation $0.315 \mathrm{p}=0.005$ ) and between lipid peroxides and thiols groups (Pearson correlation $0.23 \mathrm{p}=0.039$ ). There was a correlation between thiols and antioxidants (Pearson correlation $0.33 \mathrm{p}=0.003$ ). Lipid peroxidation and ceruloplasmin were significantly higher in patients with residual disease $(\mathrm{p}=0.039$, $\mathrm{p}=0.046$ ) emphasizing that the tumor is a generator of oxidative stress.

Conclusion: Tumor produces ROS in excess in patients with advanced ovarian adenocarcinoma. Those ROS are corelated and acts as signalling molecules.

Key words: reactive oxygen species, ovarian adenocarcinoma

\section{Introduction}

Epithelial ovarian cancer is world-wide the seventh cause of cancer in women and the eight causes of death but ovarian cancer is the commonest cause of gynaecological cancerassociated death and the second cause of gynaecological cancer, especially because the vast majority of patients presents in advanced stage (1).

Surgery with curative intent and platinumbased chemotherapy are the backbone of treatment, but more recently, combination with anti-angiogenic agents and treatment with PARP inhibitors emerged as viable options (2). Chronically activated angiogenesis is a hallmark of ovarian cancer due to an augmentation of pro-angiogenic signals thus sustaining cancer nutrition.

Reactive oxygen species (ROS) are involved in the development and progression of many cancers and has been showed to activate protumorigenic signalling, increase tumor cell survival and proliferation, DNA damage and genetic instability. Oxidative stress is defined as the imbalance between ROS and cellular 
antioxidative capacities and is based on a disruption of redox signalling $(3,4,5)$. Reactive oxygen species interact with essential macromolecular structures, especially with nucleic acids, proteins, lipids. Because these structures are essential for tumor metabolism, ROS may interact with normal cellular function (6).

Increase reactive oxygen species production has been discovered in many types of cancer but their implication in carcinogenesis and tumor progression is not yet fully understood. Elevated levels of ROS are oncogenic, may cause DNA damage, promotes genetic instability and tumorigenesis, acts as signalling molecules, cause proliferation and cancer cell survival, abnormal cell growth, invasion and metastasis and resistance to apoptosis $(5,7)$.

ROS play important role in angiogenesis by endothelial progenitor activation, signalling of vascular endothelial factor (VEGF) and angiopoietin and recruitment of perivascular cells (8).

The aim of this study was to determine the oxidative stress in patients with epithelial ovarian cancer treated with surgery and chemotherapy (platinum salts), to determine if the presence of tumor increases the production of reactive oxygen species and how measurement of oxidative stress can be integrating in treatment strategy. The hypothesis was that because of the accelerated metabolism, tumor tissue is an inductor of oxidative stress.

\section{Materials and Methods}

Thirty-five patients diagnosed in our centre with epithelial ovarian carcinoma between January 2010 and December 2017 were included in the study. The inclusion criteria consisted in women more than 18 years old, diagnosed with epithelial ovarian cancer stage II-IV who underwent surgery with radical intent (total hysterectomy and bilateral ovariectomy and excision of all macroscopic disease in the abdomen) or biopsy, ECOG performance status less than 2, willing to undergo chemotherapy. Initial workup of the patients consisted in complete blood count, liver and renal function assessment, CA125, pelvic and abdominal CT or MRI. All the patients signed the informed consent approved by the Ethics Committee of our Institute. The treatment consisted in platinum-based chemotherapy (paclitaxel $175 \mathrm{mg} / \mathrm{m}^{2}$ and Carboplatin AUC 5-6 every 3 weeks). Blood samples $(5 \mathrm{ml})$ were obtained in dynamic at the beginning of each cycle of chemotherapy (for a total of 4 samples). Serum was isolated by centrifugation, and the following determinations were performed: lipid peroxides, ceruloplasmin, thiols and antioxidants.

Lipid peroxides were evaluated by measuring the serum concentration of malondialdehyde (MDA). Spectrophotometric Carbonneau method was used and this method is based on the production of a coloured adduct (MDA-TBA2) with a maximum of absorption at $532 \mathrm{~nm}$ depending on concentration. It had normal levels between 0-4 $\mathrm{\mu mol} / 100 \mathrm{ml}$ serum;

The oxidative activity of ceruloplasmin was determined using Ravin method based on the reaction between $\mathrm{p}$-phenylen diamine in an acid acetic acetate tampon. It is a spectrophotometric method too, and the intensity of the colour developed at $540 \mathrm{~nm}$ is directly proportional to the concentration of ceruloplasmin. Normal values were registered between 80 and 120 U.I.

$\mathrm{SH}$-albumin thiols groups were measured by reaction with Ellman reactive (5,5 ditio-bis nitrobenzoic) which reached a maximum intensity at $412 \mathrm{~nm}$ concordantly with the $\mathrm{SH}^{-}$ groups. Normal levels range between 370 and $450 \mathrm{\mu mol} / \mathrm{l}$ (9).

Total antioxidants were measured starting from the ability of serum to reduce the iron (at a low $\mathrm{pH}$ the complex Felll - tripiridil-striazina is reduced at the ferrous state and an intense blue complex is formed, and the maximum of colour is at $593 \mathrm{~nm}$ ). Normal value of antioxidants is between 0.9 and $1.4 \mathrm{\mu mol} / \mathrm{l}$.

\section{Results}

Thirty-five patients with histological confirmed ovarian cancer were included in the study. The vast majority of the patients were stage III (51.4\%) and stage IV (28.6\%) and only 20\% 
stage II. Median CA-125 value was $621 \mathrm{U} / \mathrm{ml}$.

Oxidative stress was assessed by measuring malondialdehyde, ceruloplasmin, thiols and total antioxidants.

Median value of the malondialdehyde (the final product of lipid peroxidation) was 8.12 $\mu \mathrm{mol} / 100 \mathrm{ml}$ serum compare to normal value of less than $4 \mu \mathrm{mol} / 100 \mathrm{ml}$ serum.

Ceruloplasmin (CP) is a copper binding protein of acute phase, synthesized mainly in the liver, which is increased in inflammation, pregnancy and trauma. As a multifunctional enzyme ceruloplasmin shows amino-oxidase, superoxide dismutase, and ferro-oxidase activity (10). In our lot of patients, the median value of ceruloplasmin was elevated, mean value was 144.78 U.I. compare to normal value 120 U.I. showing an active oxidative process in patients with ovarian cancer.

In order to demonstrate the existence of a system that developed oxidative stress, the thiols were measured as a result of the oxidative attack to circulating proteins especially albumins. A small decrease of the normal value was noticed (395 vs. $450 \mu \mathrm{mol} / \mathrm{l})$ and that difference may be due to endogenous activation of the antioxidants.

Considering that the oxidative stress is an imbalance between ROS and antioxidants, we measured the value of total endogenous antioxidants (Table 1). An increase of the total antioxidants was noticed ( $1.44 \mathrm{vs} 1.4 \mu \mathrm{mol} / \mathrm{l})$. This concern only the non-enzymatic endogenous system and the patients has no consumption of exogenous antioxidants.

The value of ROS was evaluated in dynamic before each cycle of chemotherapy to a total of 4 determination. Lipid peroxidation levels decrease between the first determination and the last one (9.08 vs. $6.93 \mu \mathrm{mol} / 100 \mathrm{ml}$ ) (Fig. 1A). Ceruloplasmin mean levels were 169.6 U.I. at the beginning of the treatment and decreased to a value of 139 U.I. after four cycles of platinumbased chemotherapy (Fig. 1B). Thiols decreased from 375.61 to $305 \mu \mathrm{mol} / \mathrm{l}$ (Fig. 1C) and antioxidants decreased from 1.5 to $1.34 \mathrm{\mu mol} / \mathrm{l}$ (Fig. 1D).

There was a strong correlation between lipid peroxides levels and ceruloplasmin (Pearson correlation $0.315 \mathrm{p}=0.005$ ) (Fig. 2A) and between lipid peroxides and thiols groups (Pearson correlation $0.23 \mathrm{p}=0.039$ ). There was a correlation between thiols and antioxidants Pearson correlation $0.33 \mathrm{p}=0.003$ (Fig. 2B).

In order to determine if the presence of the tumor is a factor that induces oxidative stress the lot was divided in two sub-groups. First consisted in patients with stage I-II and no residual disease, and the other consisted of patients with stage III and IV with measurable tumors. In our lot of patients, lipid peroxidation was significant higher in the group of patients with tumor present (mean value was 9.9 vs. $6.7 \mu \mathrm{mol} / 100 \mathrm{ml}, \mathrm{p}=0.039)$. Regarding ceruloplasmin there was a significant increase in the value of ceruloplasmin in patients with persistent tumor (mean 187 vs. 129 U.I. $\mathrm{p}=0.046$ ). (Fig. 3A, B). There was no significant difference between antioxidants in patients with or without tumor.

In our lot of patients, median overall survival was 69 months. In order to established if the presence of reactive oxygen species is a prognostic factor we compare the overall survival of patients with malondialdehyde higher than 8 and less than $8 \mu \mathrm{mol} / 100 \mathrm{ml}$

Table 1. Value of malondialdehyde, ceruloplasmin, thiols and antioxidants

\begin{tabular}{lcccc}
\hline & Malondialdehyde & Ceruloplasmin & Thiols & Antioxidants \\
\hline Mean & 8.12 & 148.5 & 325.92 & 299 \\
Median & 7.25 & 138.5 & 1.44 & 1.36 \\
\hline Standard deviation & 2.8 & 56.9 & 53.00 & 254 \\
\hline Minimum & 4.04 & 316.00 & 852.00 & 0.4 \\
Maximum & 16.83 & $80-120 \mathrm{U} . \mathrm{I}$ & $370-450 \mu \mathrm{mol} / \mathrm{l}$ \\
\hline Normal value & $0-4 \mu \mathrm{mol} / 100 \mathrm{ml}$ & 4.1 & $0.9-1.4$ \\
\hline
\end{tabular}


A
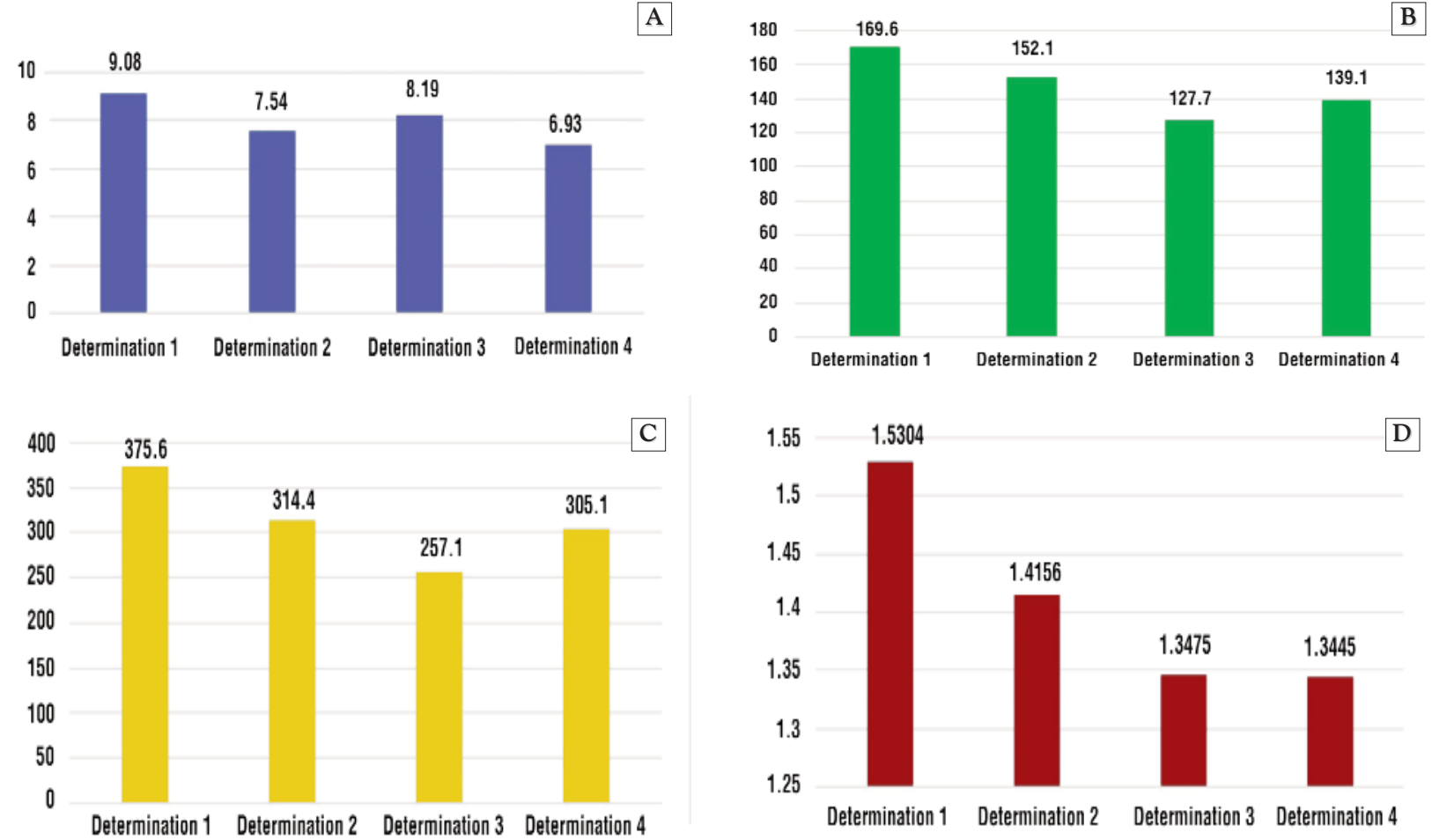

Figure 1. Determination of the lipid peroxidation reaction (A) ceruloplasmin (B), thiol compounds (C), total antioxidant level (D) in dynamic before each cycle of chemotherapy

serum; median overall survival for patients with higher malondialdehyde was 35 months compere to 100 months in patients with lower malondialdehyde, showing that this can be used as a prognostic marker in patients with ovarian cancer (Fig. 4).

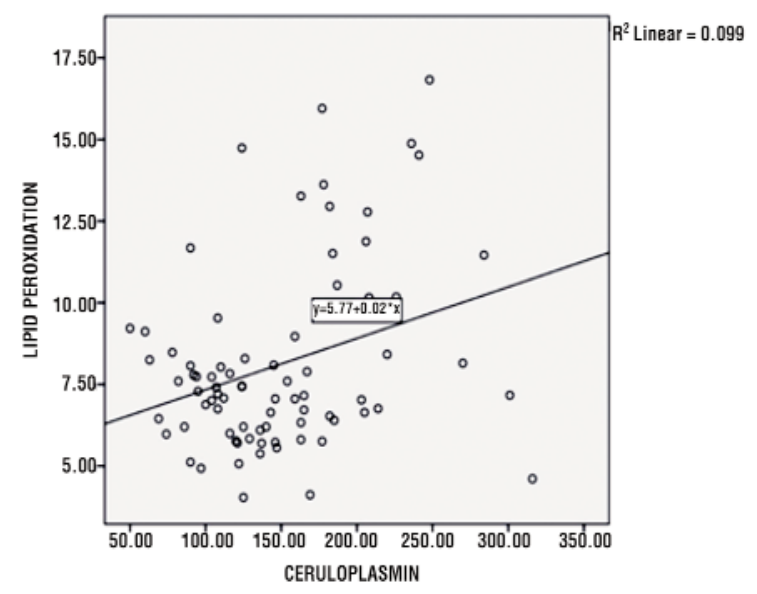

\section{Discussions}

The imbalance between the production of reactive oxygen species and elimination of free radicals leads to a state of oxidative stress and damage of the important component of the

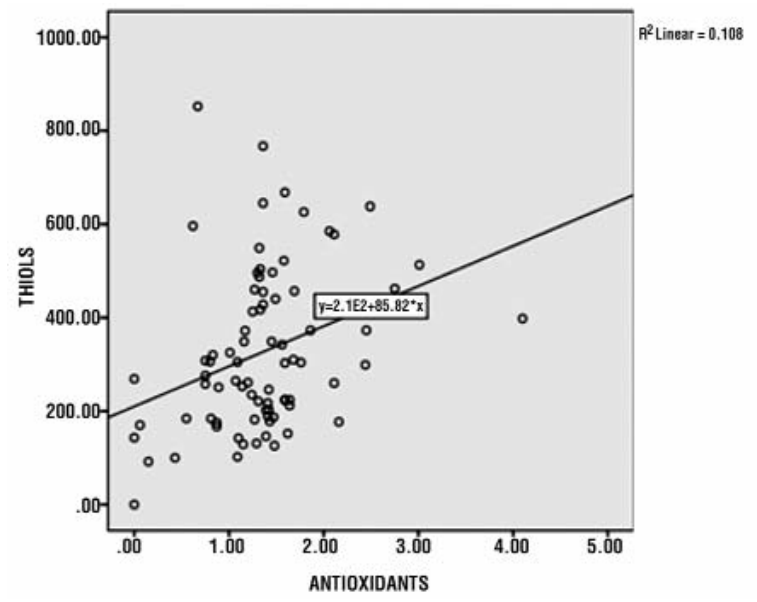

Figure 2. Correlation between lipid peroxidation and ceruloplasmin (A) and between thiols and antioxidants (B) 

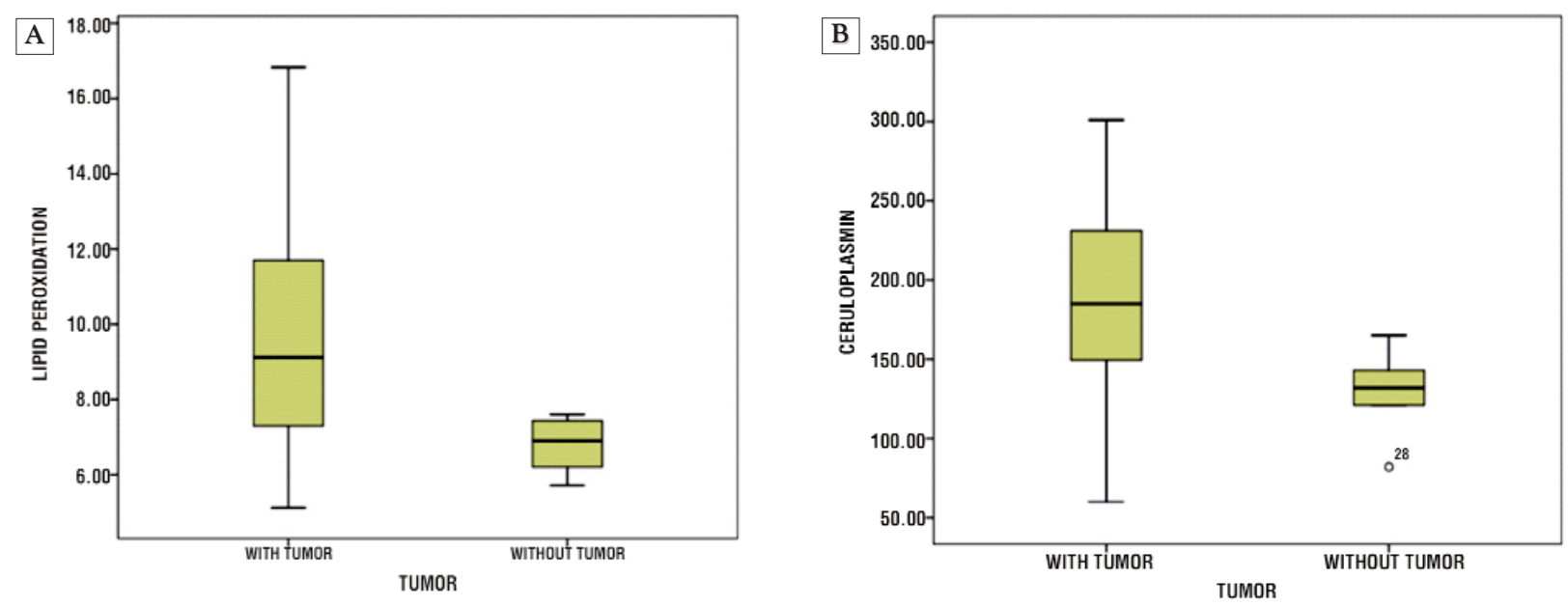

Figure 3. Value of lipid peroxidation (A) and ceruloplasmine $(B)$ in patietns with and without tumors

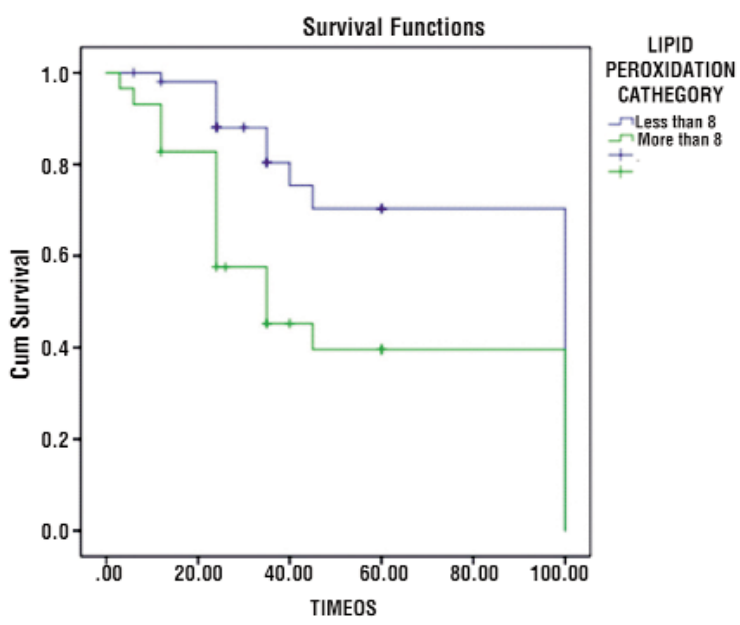

Figure 4. Difference in overall survival in patients with lipid peroxidation less or more than $8 \mu \mathrm{mol} / 100 \mathrm{ml}$

cell. (11). Oxidative stress has been showed to interfere with all phases of the oncogenic process such as initiation, promotion, progression, invasion and metastasis (12). Increase reactive oxygen species has been detected in several cancer but their role in pathogenesis and progression of cancer is not clear. ROS have been showed to activate the pro-tumorigenic signalling, enhance cell proliferation, increase cell survival, increase glucose metabolism, adaptation to hipoxia, and favour genetic instability and DNA damage (5). Tumor cell express high levels of antioxidants in order to detoxify this amount of ROS and establish the redox balance but still maintained a pro- $^{-}$ tumorigenic status and resistance to chemotherapy and apoptosis.

Lipid peroxides can be formed by the attack of radicals, such as reactive oxygen species (ROS) and reactive nitrogen species (RNS), on polyunsaturated fatty acid residues of phospholipids. The persistence of oxidative stress and excess of lipid peroxidation can cause DNA damage and dysregulation of cell homeostasis, events involved in the pathogenesis of cancer. The most investigated com- $^{-}$ pounds were malondialdehyde (MDA), acrolein, and crotonaldehyde (13). The ability of this radical to modify DNA bases yielding mutagenic lesions, is considered to contribute to carcinogenic effects associated with oxidative stress.

When ROS are in small concentration, they have a role in cell signalling, switching the cell phenotype to angiogenesis and neovascularisation which contribute to tumor growth and proliferation. On the other part the production in excess of ROS become destructive and kill cancer cells (14).

In our study, some parameters of oxidative stress were determined in order to established the role of tumor in inducing the oxidative stress. The results obtained showed that in these patients there is an increase in ROS production and that the primary target of attack is represented by lipids peroxidation. 
Malondialdehyde the final product of oxidative degradation of lipids, was much higher than the normal levels. This elevated level are the results of an intense oxide reaction by reactive oxygen species especially as a result of the oxygen metabolism. The high prevalence of lipid peroxidation as a result of ROS effects can be explained by the high probability to encounter constitutive lipids.

Similar elevated levels of malondialdehyde were reported by a study which included 42 patients with ovarian cancer and find a significant statistic difference between the group of patients with ovarian cancer and control group ( 8.7 compare to $6.7 \mathrm{nmol} / \mathrm{L}$ ). In this study malondialdehyde was not found to be prognostic (15). Another way to objectivate the increase lipid peroxidation is to measure the levels of malondialdehyde in malignant tissue and this was tested in breast and lung cancer (16). A recent study detect lipid peroxide malondialdehyde as an indicator of oxidative stress within the tissue samples of 34 ovarian cancer patients and find an eight time increase in the expression of ROS in patients with stage III and IV ovarian cancer compare to normal ovarian tissue (17).

This increase of malondialdehyde was even higher in patients who still had measurable tumor. Comparing lipid peroxidation in patients with measurable tumor vs. patients with no tumor we can conclude that the presence of the tumor induces oxidative stress which lead to increase production of free radicals participating to the lepidic peroxidation reaction. A study in patients with breast cancer find a direct correlation between stage of the disease and increase of malondialdehyde, consisting to our results (18). Ceruloplasmin levels were slightly elevated in our patients. Ceruloplasmin was tested as a diagnostic marker in patients with lung, breast, and head and neck cancer and higher levels were observed compere to control lot without cancer. Ceruloplasmin levels were corelated with tumor burden (10). A recent study showed that ceruloplasmin and transferine are increased in patients with breast cancer after radiotherapy (19). The extension of the degradation of proteins is at a much less scale, and it takes time to be activated so the thiols were not so elevated.

Because of the production in excess of ROS, we expected that the endogenous antioxidant system should be activated and the level of antioxidants will be much more elevated but this was not the case. The tumor produced in excess reactive oxygen species but it produces circulating proteins that contained sulphur and this can mimic an antioxidant action and stop the production of natural antioxidants. So, when the active metabolits of oxygen are produced in small concentration because of hipoxia, the molecular phenotype is modified throw neovascularization, and angiogenesis initiation (20). Another explanation may be the fact that chemotherapy decreased the immunity and the antioxidant responses of the organism.

Another conclusion is the fact that lipids represents the primary target of oxidative attack. Based on the data obtained by measurement of the ceruloplasmin and total thiols who were slightly elevated, we can conclude that proteins are the second target of the oxidative attack. Protein that contained sulfur are degraded to thiols and have an antioxidant activity. This are produced in excess by the tumor in order to mask the oxidative stress and it emphasise the fact the tumor has a different oxidative mechanism compare to normal tissue.

During treatment, the tumor burden decreased and as a consequence the oxidative stress decrease and this may be the explanation why lipid peroxidation and ceruloplasmine decreased during chemotherapy even if it is known that chemotherapy (especially anthracycline and platinum salt) increase oxidative stress (21).

A statistical significant correlation was found between malondialdehyde and ceruloplasmin and between thiols and antioxidants showing that this molecules interreacts and they may be used as biomarkers before and after surgery.

In patients were tumor was surgically removed the value of malondialdehyde and 
ceruloplasmine were significantly lower than in patients with macroscopic tumor, showing that tumor represents an important factor for increase oxidative stress.

\section{Conclusions}

In conclusion, the tumor produced in excess reactive oxygen species, in patients with epithelial ovarian carcinoma, and this can play an important role in invasion and metastasis. Further studies are needed in order to established that those biomarkers are prognostic or can be used to monitor the treatment response.

\section{Reference}

1. Ferlay J, Soerjomataram I, Dikshit R, Eser S, Mathers C, Rebelo M, et al. Cancer Incidence and Mortality Worldwide: Sources, methods and major patterns in GLOBOCAN 2012. Int J Cancer. 2015; 136(5):E359-86.

2. Ledermann JA, Raja FA, Fotopoulou C, Gonzalez-Martin A, Colombo $\mathrm{N}$, Sessa C. Newly Diagnosed and Relapsed Epithelial Ovarian Carcinoma: ESMO Clinical Practice Guidelines. Ann Oncol. 2013;24(Suppl 6):vi24-vi32.

3. Valko M, Rhodes CJ, Moncol J, Izakovic M, Mazur M. Free radicals, metals and antioxidants in oxidative stress-induced cancer. ChemicoBiological Interactions. 2006;160(1):1-40.

4. Lahtz C, Pfeifer GP. Epigenetic changes of DNA repair genes in cancer. Journal of molecular Cell Biology. 2011;3(1):51-58.

5. Moloney J, Cotter T. ROS signalling in the biology of cancer Seminars in Cell \& Developmental Biology. 2018 Aug;80:50-64.

6. Marnett LJ. Oxyradicals and DNA damage. Carcinogenesis. 2000 Mar;21(3):361-70.

7. Egea J, Fabregat I, Frapart Y, Ghezzi P, Görlache A, Kietzmanng T et al. European contribution to the study of ROS: A summary of the findings and prospects for the future from the COST action BM1203 (EU-ROS). Redox Biology;13(2017):94-162

8. Maulik N. Redox signaling of angiogenesis. Antioxid Redox Signal. 2002;4(5):805-15

9. Marinescu S, Anghel R, Gruia MI, Beuran M. Involvement of reactive oxygen species in the mechanisms associated with cervical cancer specific treatment. Chirurgia (Bucur). 2014 Nov-Dec;109(6):806-11.

10. Senra Varela A, Lopez Saez JJ, Quintela Senra D. Serum ceruloplasmin as a diagnostic marker of cancer. Cancer Lett. 1997;121(2): $139-45$.

11. Saed GM, Diamond MP, Fletcher N. Updates of the role of oxidative stress in the pathogenesis of ovarian cancer Gynecol Oncol. 2017; 145(3):595-602

12. Reuter S, Gupta SC, Chaturvedi MM, Aggarwal BB. Oxidative stress, inflammation, and cancer: how are they linked? Free Radic Biol Med. 2010;49(11):1603-16

13. Nair U, Bartsch H, Nair J. Lipid peroxidation-induced DNA damage in cancer-prone inflammatory diseases: a review of published adduct types and levels in humans. Free Radic Biol Med. 2007;43(8): 1109-20.

14. de Sá Junior PL, Camara DAD, Porcacchia AS, Fonseca PMM, Jorge SD5, Araldi RP, Ferreira AK The Roles of ROS in Cancer Heterogeneity and Therapy. Send to Oxid Med Cell Longev. 2017;2017:2467940.

15. Didžiapetriene J, Bublevic J, Smailyte G, Kazbariene B, Stukas R. Significance of blood serum catalase activity and malondialdehyde level for survival prognosis of ovarian cancer patients. Medicina (Kaunas). 2014;50(4):204-8.

16. Peluso M, Munnia A, Risso G, Catarzi S, Piro S, Ceppi M, et al. Breast fine-needle aspiration malondialdehyde deoxyguanosine adduct in breast cancer. Free Radic Res. 2011;45:477-82.

17. Cohen S, Mehrabi S, Yao X, Millingen S, Aikhionbare FO. Reactive Oxygen Species and Serous Epithelial Ovarian Adenocarcinoma. Cancer Res J (N Y N Y). 2016;4(6):106-114.

18. Sener DE, Gönenç A, Akinci M, Torun M. Lipid peroxidation and total antioxidant status in patients with breast cancer. Cell Biochem Funct 2007:25:377-82.

19. Krzyminiewski R, Dobosz B, Kubiak T The influence of radiotherapy on ceruloplasmin and transferrin in whole blood of breast cancer patients. Radiat Environ Biophys. 2017;56(4):345-352

20. Galanis A, Pappa A, Giannakakis A, Lanitis E, Dangaj D, Sandaltzopoulos R. Reactive oxygen species and HIF-1 signalling in cancer. Cancer Lett. 2008;266(1):12-20.

21. Pugazhendhi A Toxicity of Doxorubicin (Dox) to different experimental organ systems. Life Sci. 2018;200:26-30 